Scientific Journal of October 6 University

ISSN (Print): 2314-8640

ISSN (Electronic): 2356-8119

Published by October 6 University @ All Rights Reserved

Available online at: sjou.journals.ekb.eg

Original Article
Citation: Eldourghamy et al., (2016). Production and Purification of Heparin Degrading Enzyme from Bacillus cereus upon Biodegradation of Domestic Chicken Slaughter Byproducts. Sci. J. of Oct. 6 Univ.3(1), 1427

Copyright: (C) 2016 Eldourghamy et al. This is an open-access article distributed under the terms of the Creative Commons Attribution License, which permits unrestricted use, distribution, and reproduction in any medium, provided the original author and source are credited.

\title{
Production and Purification of Heparin Degrading Enzyme from Bacillus Cereus upon Biodegradation of Domestic Chicken Slaughter Byproducts
}

\author{
Ayman S. Eldourghamy, Adel K. Khairallah and Abdelhameed M. Othman \\ * Environmental Biotechnology Dept. Genetic Engineering and Biotechnology Research Institute (GEBRI). \\ University of Sadat City
}

\section{Received: 27-11-2014/ Revised: 02-12-2014 / Accepted: 3-01-2015}

\begin{abstract}
A Bacillus cereus strain was isolated from Egyptian soil area after a rapid screening in Menufia governorate to select heparinase hyper-producing microbes. The strain gave an enzyme production of $159.6 \mathrm{U} / \mathrm{ml}$ after 192 hours of incubation on PYH medium. Chicken slaughter byproducts were used as a supplement for production of pharmaceutical heparinase. The environmental waste was used with different concentrations $(1 \%, 5 \%, 10 \%$, $15 \%$ and $20 \%$ ) to optimize the process of bioremediation. Enzyme production was gave maximum when using a waste percentage of $15 \%$. Optimum production of the extracellular enzyme was obtained at $\mathrm{pH} 9.5$ and $37^{\circ} \mathrm{C}$. Produced enzyme was determined both biochemically and electrochemically in the microbial liquid culture to evaluate the efficiency of the polyion detection method in enzyme detection and both methods gave a similar results. Extracellular heparinase enzyme was purified with gel filtration. Specific activity of the purified enzyme reached $152.12(\mathrm{U} / \mathrm{mg})$.
\end{abstract}

Key Words: Heparinase, Bacillus, Bioremediation, slaughter wastes, polyion detection, gel filtration.

\section{Introduction}

Huge amounts of wastes are annually discarded into the environment as a result of different scientific, technological and industrial activities. These wastes are dumped into different ecosystems causing serious environmental problems for mankind on earth. Generally, wastes are disposed by digging into the ground. Other common technologies for waste disposal are high temperature incineration and chemical decomposition but these methods are complex, high cost, and may produce highly risk hazards and biohazards materials. So, bioremediation techniques are the most effective biotechnological solutions for this kind of problems ${ }^{(1)}$.

Enzymes are considered to be a class of the most effective bioremediation products. Enzymes from microbial origin are preferred than those produced by animals and plants. This is attributed to the high growth rates of microbes on inexpensive media compared to plant and animal cells, thus providing a higher yield of enzymes in a shorter period of time.

Heparinases are enzymes that belong to eliminases class. Heparinases are capable of specifically cleave the major glycosidic linkages between amino sugars and uronic acids in heparin and heparan sulfate (HS). On the industrial scale, heparinases are the main producers of low molecular weight heparins (LMWHs) ${ }^{(2)}$. Heparin has been used as the standard compound for treatment of patients with acute myocardial infarction (AMI), unstable angina (UA), thrombosis, deep vein thrombosis, or pulmonary embolism ${ }^{(3)}$. Heparin and low molecular weight heparins constitute a huge pharmaceutical market (4) and constitute about $77 \%$ share of all antithrombotics sales worldwide, where LMWHs alone constitute $72 \%$ of the total market share ${ }^{(5)}$.

This class of enzymes is also known as inhibitors of neovascularization ${ }^{(6)}$, tumour growth and metastasis ${ }^{(7)}$. LMWHs are mainly used as anticoagulant, antiangiogenic, antitumour and antimalarial agents ${ }^{(8-11)}$.

Heparinases have been classified into three groups depending on the specificity of their action on heparin or HS. These groups are heparinase I (E.C. 4.2.2.7), that acts mainly on heparin; heparinase II acts on both heparin and HS; and heparinase III (E.C.4.2.2.8) which acts mainly on HS. 
Heparinases, of all the three groups, are commercially available from Pedobacter heparinus (12)

A few other bacteria such as Bacillus sp., Sphingobacterium sp., Bacillus circulans, Bacteroides sp., Aspergillus flavus and Acinetobacter calcoaceticus are also reported to produce heparinase ${ }^{(13-19)}$.

Screening of the microorganisms for heparinase production has not yet been carried out in Egypt. Neither heparinase, nor enzymatically generated low molecular weight heparins (LMWHs) are being produced commercially in the country.

Therefore, there is a need for effective production of the heparinase enzyme by novel microbial sources and bioremediation of wastes especially in a developing country like Egypt.

\section{Materials and methods \\ Waste samples collection and screening for isolation of heparin degrading microorganisms:} Three waste samples were collected from different areas of the sampling location from El-Menoufia Governorates in Egypt ( Farmyard manure waste (FYM) collected from Abo Awally village, Slaughter waste sample (SWS) collected from Greace village and Bio laboratory Waste sample (BWS) collected from Al Eman laboratory in Abo awally village).

FYM was taken after the removal of about $10 \mathrm{~cm}$ of the top surface of farmyard manure waste, and then kept in clean plastic bags. Then $5 \mathrm{gm}$ from waste was suspended in $100 \mathrm{ml}$ of normal saline $(\mathrm{NaCl} 0.85 \%)$ and vortexed vigorously for 2 minutes. The soil particles were allowed to settle, $0.1 \mathrm{ml}$ from supernatant were spread plated on to PA medium on Petri dish and incubated for 48 hours at $37^{\circ} \mathrm{C}$. Microbial colonies were selected and obtained by plate streaking method.

SWS was taken from animal slaughter waste in sterile glass container. Then one $\mathrm{ml}$ from waste was inoculated in $100 \mathrm{ml}$ of normal saline $(\mathrm{NaCl}$ $0.85 \%), 0.1 \mathrm{ml}$ was spread plated on PA medium and incubated for 48 hours at $37^{\circ} \mathrm{C}$. Microbial colonies were selected and obtained by plate streaking method.

Half $\mathrm{ml}$ from (BWS) was inoculated in $100 \mathrm{ml}$ of normal saline $(\mathrm{NaCl}, 0.85 \%), 0.1 \mathrm{ml}$ was spread plated on PA medium and incubated for 48 hours at $37^{\circ} \mathrm{C}$. Microbial colonies were selected and obtained by plate streaking method.

\section{Growth media}

The growth media used through this work are described below, where the media composition was given as $\mathrm{g} / \mathrm{l}$ of distilled water $\mathrm{pH}$ of each medium was adjusted to the recommended $\mathrm{pH}$ and sterilized at $121^{\circ} \mathrm{C}$, for $20 \mathrm{~min}$.
Peptone yeast extract (PY) medium:

Contained (10 g peptone, $5 \mathrm{~g}$ yeast extract, and $5 \mathrm{~g}$ $\mathrm{NaCl}$ per liter. PA medium was PY medium supplemented with $15 \mathrm{~g}$ agar per liter). The $\mathrm{pH}$ value was adjusted to 7.0 by the addition of diluted $\mathrm{NaOH}$. PY and PA media were used to activate and to grow the bacterial strains ${ }^{(20)}$.

\section{Enrichment culturing liquid medium:}

Contained $(0.1 \%$ sodium heparin, $0.1 \%$ ammonium sulfate in $0.1 \mathrm{M}$ phosphate buffer. the chloride salts of magnesium, calcium, ferrous, manganous, and molybdate were added in a final concentration of $0.1 \mathrm{mg}$ per liter for each). $\mathrm{pH}$ of the medium was adjusted to 7.4 by addition of diluted $\mathrm{NaOH}^{(21)}$.

\section{Heparinase assay plates medium (HSM)}

Contained $(0.25 \mathrm{M}$ sodium acetate, $0.0025 \mathrm{M}$ calcium acetate, $1.0 \mathrm{~g}$ of porcine intestinal mucosal heparin per liter, and for solidification, $1.5 \%$ agarose was added). $\mathrm{pH}$ of the medium was adjusted to 7.4 by addition of diluted $\mathrm{NaOH}^{(22)}$.

\section{PYH medium:}

Contained $(0.75 \%$ polypeptone, $0.5 \%$ yeast extract, $0.3 \%$ sodium heparin, $0.1 \% \mathrm{~K}_{2} \mathrm{HPO}_{4}, 0.02$ $\% \mathrm{MgSO}_{4} 7 \mathrm{H}_{2} \mathrm{O}, 0.1 \% \mathrm{NaCl}$. pH of the medium was adjusted to 7.4 by addition of diluted $\mathrm{NaOH}$ (16)

\section{Heparinase production in enrichment culturing liquid media:}

The screened previous isolates were inoculated in $100 \mathrm{ml}$ of Enrichment media in $250 \mathrm{ml}$ Erhlenmeyer flasks and incubated at $37{ }^{\circ} \mathrm{C}$ for 96 hours. At 24 hours interval, $1 \mathrm{ml}$ samples were taken and the cells were harvested by centrifugation at $(6000 \times g$ for 5 minutes $)$ in $1.5 \mathrm{ml}$ Eppendorff tubes. The supernatant was separated in $1.5 \mathrm{ml}$ Eppendorff tubes to determine the activity of extracellular heparinase enzyme by Crystal Violet dye methods ${ }^{(23)}$.

\section{Heparinase production in PYH Media:}

The screened heparin degrading isolates were inoculated in $100 \mathrm{ml}$ of PYH medium in $250 \mathrm{ml}$ Erhlenmeyer flasks and incubated at $37^{\circ} \mathrm{C}$ for 192 hours. At 24 hours interval, $1 \mathrm{ml}$ from sample was withdrawn and the cells were harvested by centrifugation at $(6000 \times g$ for 5 minutes $)$ in Eppendorff tubes. The supernatant withdrawn in Eppendorff tubes to detection of heparinase activity by Crystal Violet dye methods.

\section{Heparinase production by utilization of blood waste:}

Preparation of blood containing waste

The blood containing waste (from domestic chickens) was prepared first by drying at room temperature, to get rid of most of its moisture 
content, then it was dried at $60^{\circ} \mathrm{C}$ for 24 hours and it was ground with a laboratory blender.

\section{Monitoring growth and extracellular heparinase production}

The screened heparin degrading isolate were inoculated in $100 \mathrm{ml}$ of PYH medium supplemented with different concentration of dried blood waste $(1 \%, 5 \%, 10 \%, 15 \%$ and $20 \%)$ in 250 $\mathrm{ml}$ Erhlenmeyer flasks to reach the optimal concentration of blood waste that give high extracellular heparinase production. Monitoring the isolates growth and the extracellular heparinase production was carried out by Crystal Violet dye methods.

\section{Optimization of heparinase production Determination of optimum temperature}

The screened isolate were inoculated in $100 \mathrm{ml}$ of PYH medium in $250 \mathrm{ml}$ Erhlenmeyer flasks and at different value of temperature $\left(25^{\circ} \mathrm{C}, 30^{\circ} \mathrm{C}, 37^{\circ} \mathrm{C}\right.$, $45^{\circ} \mathrm{C}, 50^{\circ} \mathrm{C}$ ) and incubated for 96 hours. Monitoring the isolate growth and the extracellular heparinase production was achieved spectrophotometry by using Crystal Violet dye methods.

\section{Determination of optimum pH}

The screened isolate were inoculated in $100 \mathrm{ml}$ of PYH medium in $250 \mathrm{ml}$ Erhlenmeyer flasks and adjust $\mathrm{pH}$ at different value $(5.4,6.4,7.4,8.5,9.5$, $10.5)$ and incubated at $37^{\circ} \mathrm{C}$ for 96 hours. Monitoring the isolate growth and the extracellular heparinase production was achieved spectrophotometry by using Crystal Violet dye methods.

\section{Determination of heparinase activity. Heparinase plate assay.}

The microorganisms isolated by enrichment culturing method were further screened for heparinase production in heparinase plate assay as described by Zimmerman ${ }^{(22)}$. The isolated microorganisms were grown on the HSM medium supplemented with $2 \%$ bacteriological agar, (portions of single colonies grown on PA plates were picked and transferred by clean sterilized toothpicks to HSM plates). Plates were marked and oriented on a graph paper and incubated at $30^{\circ} \mathrm{C}$ for $72-120$ hours. Subsequently, $2 \%$ protamine sulfate solution was added on the plate and incubated at $30^{\circ} \mathrm{C}$ for $1-2$ hours. The interaction of protamine sulfate with unconsumed heparin in the plate resulted in the formation of white colored precipitates. The formation of a clearance zone around the microbial culture indicated heparin breakdown by heparinase produced by the microorganism.

Colonies that produced considerable clear zones on HSM plates were screened for a second time. B. circulans ATCC 4513 strain (from VACSERA) was also tested as a heparinase producing strain. After the incubation period, the growth diameter of each bacterial colony was scored as $(\mathrm{y} \mathrm{cm})$ and the whole diameter (growth diameter including the clear zone) was scored as $(\mathrm{x} \mathrm{cm})$. The ratio (x/y) was taken as the base to choose the best heparinase producing bacterial strains.

Spectrophotometric assay of heparinase activity The heparin molecule is negatively charged and can easily interact with cationic dyes. Based on this principle, the interaction of heparin with crystal violet was investigated with a spectrophotometric method to detect the enzyme activity. Decrease in absorbance of color indicated a heparin degrading activity and production of heparinase enzyme by the isolates (One unit of enzyme activity will decrease absorbance at $650 \mathrm{~nm}$ by 0.01 in 20 minute at $30 \mathrm{oC}$ )

Crystal violet was selected as the bioprobe to investigate the binding reaction with heparin. It is a kind of basic triphenylmethane dye commonly used in the analytical laboratory and can easily be obtained at low cost.

The stock solution of heparin was prepared directly by dissolving $0.1 \mathrm{~g}$ of heparin sodium reagent (sodium salt, $120 \mathrm{IU} \mathrm{mg}^{-1}$ ) in double distilled water. The whole solution was diluted to $100 \mathrm{ml}$ and stored at $4{ }^{\circ} \mathrm{C}$. Crystal violet was prepared by dissolving $0.041 \mathrm{~g}$ crystal violet in water. Solution was brought to $100 \mathrm{ml}$ distilled water to be used as a stock. Britton-Robinson (B-R) buffer solution was prepared by mixing $12.35 \mathrm{~g}$ boric acid, 13.55 $\mathrm{ml} 85 \%$ phosphoric acid and $11.80 \mathrm{ml}$ acetic acid and the whole mixture was diluted to $1 \mathrm{~L}$ and adjusted to $\mathrm{pH} 3.0$ by diluted solution of sodium hydroxide ${ }^{(23)}$.

All other reagents were of analytical reagent grade and were used without further purification.

To a dry glass tube, solutions were added in the following order: $1.5 \mathrm{ml}$ of $\mathrm{B}-\mathrm{R}(\mathrm{pH} 3.0)$ buffer solution, $2.5 \mathrm{ml}$ crystal violet. The mixtures were diluted to $10 \mathrm{ml}$ with water, mixed homogeneously and allowed to stand at $25^{\circ} \mathrm{C}$. Subsequently $0.5 \mathrm{ml}$ from the above solution was mixed with $0.5 \mathrm{ml}$ from supernatant of bacterial culture and allowed to stand at $25^{\circ} \mathrm{C}$ for $20 \mathrm{~min}$. After incubation, the absorbance of solution (A) was recorded at $363 \mathrm{~nm}$ and $650 \mathrm{~nm}$ against blank sample $(0.5 \mathrm{ml} \mathrm{PYH}$ medium with $0.5 \mathrm{ml}$ Crystal violet solution). The absorbance $\left(\mathrm{A}_{0}\right)$ of the blank sample was obtained under the same conditions, and thus the difference of absorbance $\left(\Delta \mathrm{A}=\mathrm{A}_{0}-\mathrm{A}\right)$ was taken as the real value for enzymatic activity.

Electrochemical detection of heparinase activity Preparation of polyanion-sensitive electrode Polyanion-sensitive membrane electrodes were prepared according to the method described by Durust ${ }^{(24)}$, the membrane casting solution was prepared with the following composition: $66 \mathrm{wt} \%$ 
high-molecular-weight poly (vinyl chloride) (PVC) (Fluka, Ronkonkoma, NY), 32.5 wt\% bis(2ethylhexyl) sebacate (DOS), and 1.5 wt $\%$ tridodecylmethylammonium chloride (TDMAC) (Fluka). Membrane components were dissolved in distilled tetrahydrofuran (THF) $(100 \quad \mathrm{mg}$ components per $\mathrm{ml}$ of $\mathrm{THF})$. Electrodes were prepared by dipcoating the resulting solution (10 times at 15 min intervals) onto the rounded ends of glass capillaries (i.d. $\approx 1.5 \mathrm{~mm}$ ) and drying overnight. After soaking the electrodes for $2 \mathrm{~h}$ in deionized water (to decrease adhesion of the membrane with the inner glass capillaries), the glass capillaries were carefully removed and the tubes were filled with $50 \mathrm{mM}$ Tris, $\mathrm{pH} 7.4$, containing $120 \mathrm{mM} \mathrm{NaCl}$. Electrochemical EMF measurements were made vs a $\mathrm{Ag} / \mathrm{AgCl}$ reference electrode using a VF-4 (World Precision Instruments, Sarasota, FL).

\section{Calibration of polyanion-sensitive electrode}

Sensors were calibrated for heparin by adding small aliquots, $100 \square \mathrm{l}$ of $1-10 \square \mathrm{g} / \mathrm{ml}$ heparin solutions, respectively, to $4.9 \mathrm{ml}$ of Tris- $\mathrm{HCl}$ buffer with continuous stirring of the test solution at a constant rate. The EMF changes of the membrane electrodes were measured 2 min following each sequential addition of heparin solution, at which time the non-equilibrium steady-state potential had been reached. Calibration curves were plotted using the net potential change from the baseline value $(\triangle \mathrm{EMF})$ versus the concentration of the polyanion.

\section{Microbial identification \\ Gram stain examination}

A smear of the isolates was prepared on a clean glass slide and the smear was allowed to air dry and then heat fixed. The heat- fixed smear was flooded with crystal violet and after one minute, it was washed with water and flooded with mordant gram's iodine. The smear was decolorized with 95\% ethyl alcohol, washed with water and then counter - stained with safranin for 45 seconds. After washing with water, the smear was dried wit tissue paper and examined under oil immersion $(100 x)^{(25)}$.

\section{Catalase test}

The Catalase enzyme serves to neutralize the bactericidal effects of hydrogen peroxide. Catalase enzyme breaks hydrogen peroxide $\left(\mathrm{H}_{2} \mathrm{O}_{2}\right)$ into water and oxygen. This reaction is characterized by the rapid formation of bubble. ${ }^{(26)}$

\section{Slide (drop) method}

A microscope slide was placed inside a Petri dish. Using a sterile inoculating loop a small amount of organism was collected from a well-isolated 18 to 24 hour colony and placed onto the microscope slide. Then one drop of $3 \% \mathrm{H}_{2} \mathrm{O}_{2}$ was applied onto the microscope slide without mixing. Immediately the Petri dish was covered with a lid to limit aerosols and observe for immediate bubble formation $\left(\mathrm{O}_{2}+\text { water }=\text { bubbles }\right)^{(27)}$.

3.6.3. Oxidase test

The oxidase test is a biochemical reaction that assays for the presence of cytochrome oxidase, an enzyme sometimes called indophenol oxidase. In the presence of an organism that contains the cytochrome oxidase enzyme, the reduced colorless reagent becomes an oxidized colored product ${ }^{(28)}$. 3.6.3.1. Filter Paper Test Method

Freshly prepared colonies (18 to 24 hour culture) were applied on a treated filter paper. 1 or 2 drops of $1 \%$ Kovács oxidase reagent ( $1 \%$ tetra-methyl-pphenylenediamine dihydrochloride, in water) was stored at $4^{\circ} \mathrm{C}$ in a dark bottle no longer than 1 week till use. The solution was applied to the microbial smear and color changing was observed. Microorganisms are oxidase positive when the color changes to dark purple within 5 to 10 seconds. Microorganisms are delayed oxidase positive when the color changes to purple within 60 to 90 seconds. Microorganisms are oxidase negative if the color does not change or it takes longer than 2 minutes ${ }^{(29)}$.

\section{Molecular identification of the isolates}

The bacterial isolates were characterized by ribosomal RNA (rRNA) gene sequence homology studies at Sigma for Scientific Services Company. The 16S rRNA gene of bacterial isolate was subjected to partial PCR amplification by a forward primer, complementary to nucleotides (nt) 9 to 27 and a reverse primer, complementary to nt 1512 to 1492 of two highly conserved regions ${ }^{(30)}$.

Pair-wise sequence alignment of partial rRNA gene sequences of both the isolates was performed to identify closely related homologs with the help of BLAST search tool available at NCBI webserver. Phylogenetic tree was constructed to predict the species level characterization of the studied isolates.

\section{Resistance to antibiotics}

Resistance to the antibiotics was determined on PA plates using the freeze-dried filter paper discs according to the method described by Goodfellow (31). Discs $(5 \mathrm{~mm}$ diameter) of filter paper (Whatman No.1) were soaked in a filter sterilized antibiotics solution at the selected concentration for $2 \mathrm{~min}$. These were then freeze- dried for $90 \mathrm{~min}$. and stored in sealed vials at $4{ }^{\circ} \mathrm{C}$. Test strain inoculum was spread over the surface of the plate. Antibiotic discs were placed onto the plates using sterile forceps. Presence of inhibition zone which noted after $14-30 \mathrm{hr}$. at $30{ }^{\circ} \mathrm{C}$ was recorded as negative. 
Purification of heparinase enzyme

Precipitation of heparinase by $\left(\mathrm{NH}_{4}\right)_{2} \mathrm{SO}_{4}$

The extracellular heparinase produced by Bacillus cereus was precipitated separately by ammonium sulfate in order to choose a convenient method to purify the enzyme. A hundred ml PYH medium were inoculated with recently activated Bacillus cereus cells. Cells were allowed to grow at $37^{\circ} \mathrm{C}$ for 96 hours, after which the culture was centrifuged at 7,000 rpm for 20 minutes. One $\mathrm{ml}$ sample was taken from each crude enzyme solution to determine the protein content and the heparinase enzyme activity. Then crude enzyme sample was precipitated with solid ammonium sulfate in an icebath and stirred slowly then it was allowed to stand for 1 hour at $4^{\circ} \mathrm{C}$. The mixtures were centrifuged at $12,000 \mathrm{rpm}$ for 30 minutes. Pellets were dissolved in a minimal volume of $0.1 \mathrm{M}$ Tris-HCl buffer, $\mathrm{pH}$ 7.5 then they were dialyzed overnight against the same buffer. The protein content and the heparinase enzyme activity for the dialyzed enzyme samples were determined as above.

Optimization of ammonium sulfate precipitation Bacillus cereus was grown on PYH medium at $37^{\circ} \mathrm{C}$ for 192 hours. The culture was then centrifuged at 7,000 rpm for 20 minutes at $4^{\circ} \mathrm{C}$. The cell-free supernatant $(80 \mathrm{ml})$ was then taken and chilled to $4{ }^{\circ} \mathrm{C}$ in order to be precipitated by different concentrations of $\left(\mathrm{NH}_{4}\right)_{2} \mathrm{SO}_{4}(30 \%, 40 \%$, $50 \%, 60 \%, 70 \%$, and $80 \%)$.(Clark and Switzer, 1977). Solid $\left(\mathrm{NH}_{4}\right)_{2} \mathrm{SO}_{4}$ was added to the crude enzyme solution to reach the above concentrations then it was stirred slowly in an ice-bath. After standing at $4^{\circ} \mathrm{C}$ for at least 1 hour, the precipitates were removed by centrifugation at $12,000 \mathrm{rpm}$ for 30 minutes at $4^{\mathrm{O}} \mathrm{C}$. Pellets were resuspended in a small volume of $0.1 \mathrm{M}$ Tris- $\mathrm{HCl}$ buffer, $\mathrm{pH} 7.5$ and dialyzed overnight against the same buffer ${ }^{(32)}$. Samples were taken to determine the protein content and the heparinase enzyme activity.

\section{Protein determination}

Determination of soluble proteins was carried out according to Lowry methods ${ }^{(33)}$.

\section{Preparation of dialysis tube}

Dialysis tube was prepared according to a procedure reported by Maniatis ${ }^{(34)}$

\section{Purification of heparinase by Sephadex G-50 column}

The extracellular heparinase was purified using $\left(\mathrm{NH}_{4}\right)_{2} \mathrm{SO}_{4}$ precipitations followed by a gel filtration on a (Sephadex G-50) column. Solid $\left(\mathrm{NH}_{4}\right)_{2} \mathrm{SO}_{4}(60 \%$ saturation) was added to crude enzyme solution after which precipitation and dialysis were carried out as mentioned above.

\section{Preparation of the sephadex G-50 column}

Sephadex G-50 (Pharmacia Fine Chemical, batch \#13802, mesh size $10-40 \mu$ ) $5 \mathrm{~g}$ was suspended in excess of buffer A $(50 \mathrm{mM}$ Tris-HCl, $\mathrm{pH} 7.5$ containing) in order to be swelled. The swelling process was carried out by placing the gel slurry in a water bath at $80^{\circ} \mathrm{C}$ for 3 hours. Entrapped air bubbles were removed from the gel slurry with the aid of a water pump. The gel suspension was allowed to cool and settle after which the excess eluant was removed until fairly thick slurry is formed. The slurry was poured carefully into the column with the aid of a glass rod. The addition of gel suspension was continued until a bed height of $23 \mathrm{~cm}$ then buffer reservoir was connected to the top of the column and the flow of buffer A was maintained at a rate of $36 \mathrm{ml} /$ hour for a suitable time. The bed height was adjusted to $20 \mathrm{~cm}$ by settling the gel beads and the column was then washed and equilibrated with buffer $\mathrm{A}$ at a flow rate of $36 \mathrm{ml} /$ hour using a peristaltic pump (LKB model 2120). The procedure above was carried out at $4^{\circ} \mathrm{C}$ in a cold box (LKB 2203 Mini cold lab).

\section{Fractionation of enzyme sample}

Two $\mathrm{ml}$ of the dialyzed heparinase was applied to the Sephadex G-50 $(1.5 \times 20 \mathrm{~cm})$ column with the aid of an adaptor. The enzyme was eluted with 0.1 $\mathrm{M}$ Tris- $\mathrm{HCl}, \mathrm{pH} 7.5$ containing $10 \mathrm{mM} \mathrm{CaCl}_{2}$ at a flow rate of $36 \mathrm{ml} /$ hours. Fractions $(3 \mathrm{ml}$ ) were collected at $4^{\circ} \mathrm{C}$ after which the absorbance at 280 $\mathrm{nm}$ and the enzyme activity were determined. Active fractions were collected and reprecipitated on ice with solid $\left(\mathrm{NH}_{4}\right)_{2} \mathrm{SO}_{4}$. After standing overnight at $4^{\circ} \mathrm{C}$, the precipitate was removed by centrifugation at $12,000 \mathrm{rpm}$ for 30 minutes at $4^{\circ} \mathrm{C}$. The precipitate was redissolved in a small volume of the above buffer and stored at $-20^{\circ} \mathrm{C}$ to be used in the characterization experiments.

\section{Results \\ Samples collection and screening for heparin degrading microorganisms}

In an attempt to screen of waste samples for isolation of heparin degrading microorganism, twenty four isolates were screened from different Egyptian areas in El-Menoufia Governorate, Egypt. Isolates were grown on PA medium and incubated for 48 hours at $30^{\circ} \mathrm{C}$ and then purified by streaking methods.

\subsubsection{Primary screening for heparinase producing microorganisms}

To test for the ability of screened isolates to produce heparinase enzyme, the twenty four isolates were grown on Enrichment culturing liquid medium containing heparin as the sole carbon source. Twenty five percent from these isolates were able to grow and produce heparinase and were further subjected to heparinase plate assay. Figure (1) 
Selection of these organisms was based on the growth of the isolates on Enrichment media and their ability to produce heparinase. Enrichment culturing liquid medium was applied as a screening medium to avoid any carbon metabolite inhibition of heparinase production as well as to enhance heparinase production by using heparin at $1 \%(\mathrm{w} / \mathrm{v})$ concentration.

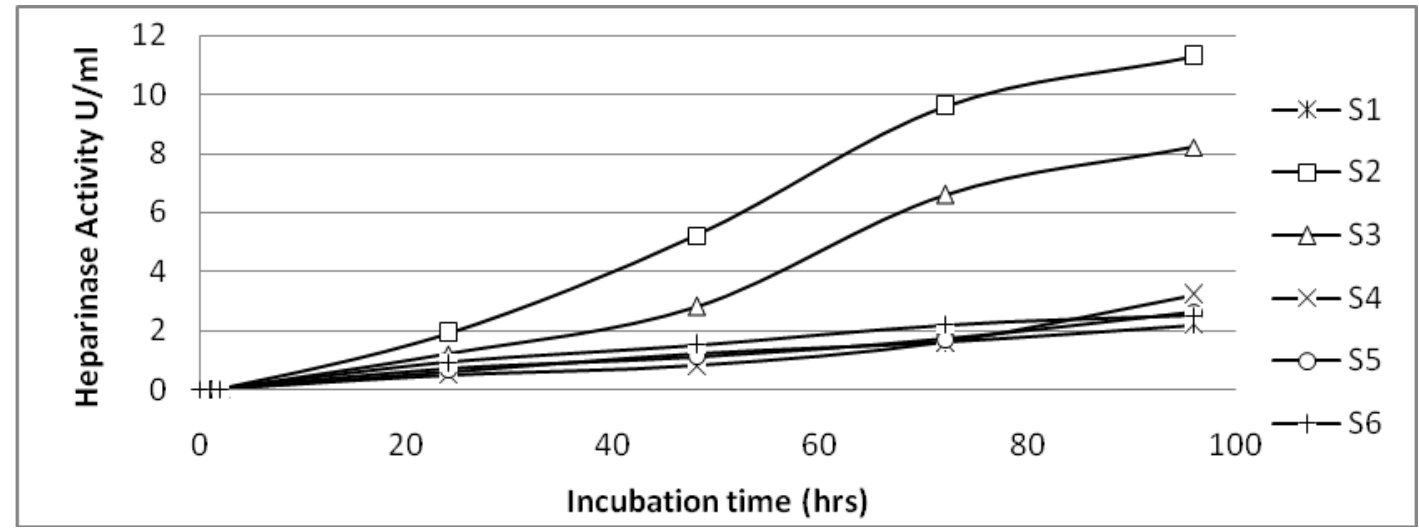

Figure 1: Heparinase production by isolates grown on Enrichment culturing liquid media.

The results obtained in Figure (1) showed that heparinase production by both $\mathbf{S 2}$ and $\mathbf{S 3}$ cultures was gave highest level of enzyme activity $11.3 \mathrm{U} / \mathrm{ml}$ and $8.3 \mathrm{U} / \mathrm{ml}$ respectively after 96 hours of incubation. With further incubation heparinase production decreased for both cultures.

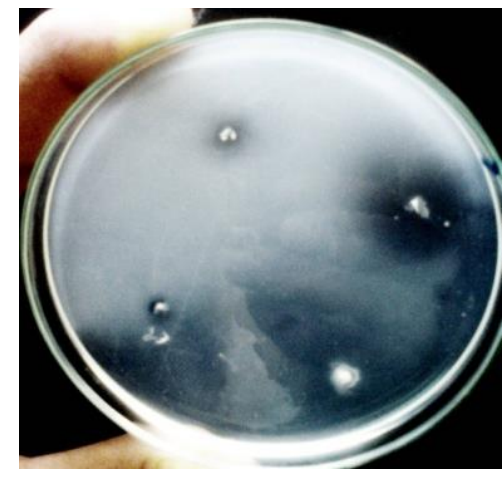

Bacillus circulans

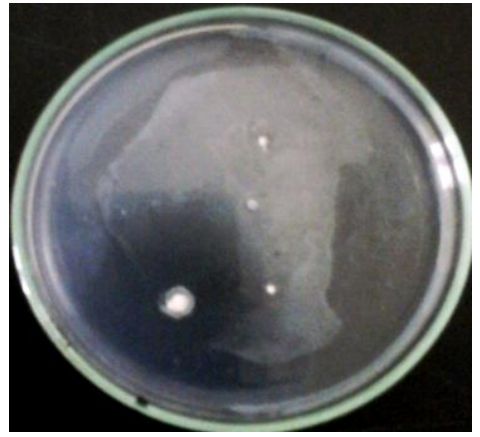

Isolate No 2

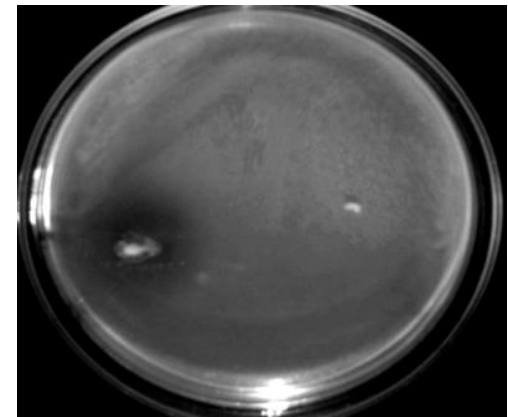

Isolate No 3

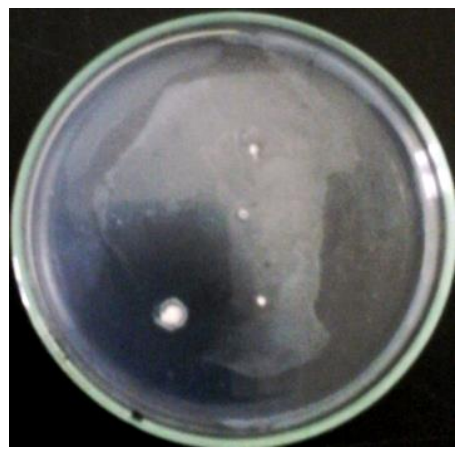

Isolate No 2

Figure 2: Heparinase plate assay (a) Bacillus circulans (b) isolate No. 3 (b) isolate No.2. 
Table (1): Heparinase production by screened isolates in plate assay

\begin{tabular}{l|ccc}
\hline Isolate no. & $\begin{array}{c}\text { Diameter of bacterial } \\
\text { colony }(\mathbf{y})\end{array}$ & $\begin{array}{c}\text { Whole diameter of clear } \\
\text { zone }(\mathbf{x})\end{array}$ & $\begin{array}{c}\text { Enzyme } \\
\text { activity }\end{array}$ \\
\hline S2 & 2.8 & 35 & 12.5 \\
S3 & 2.7 & 31 & 11.5 \\
B. circulans & 3.0 & 27 & 9.0 \\
\hline
\end{tabular}

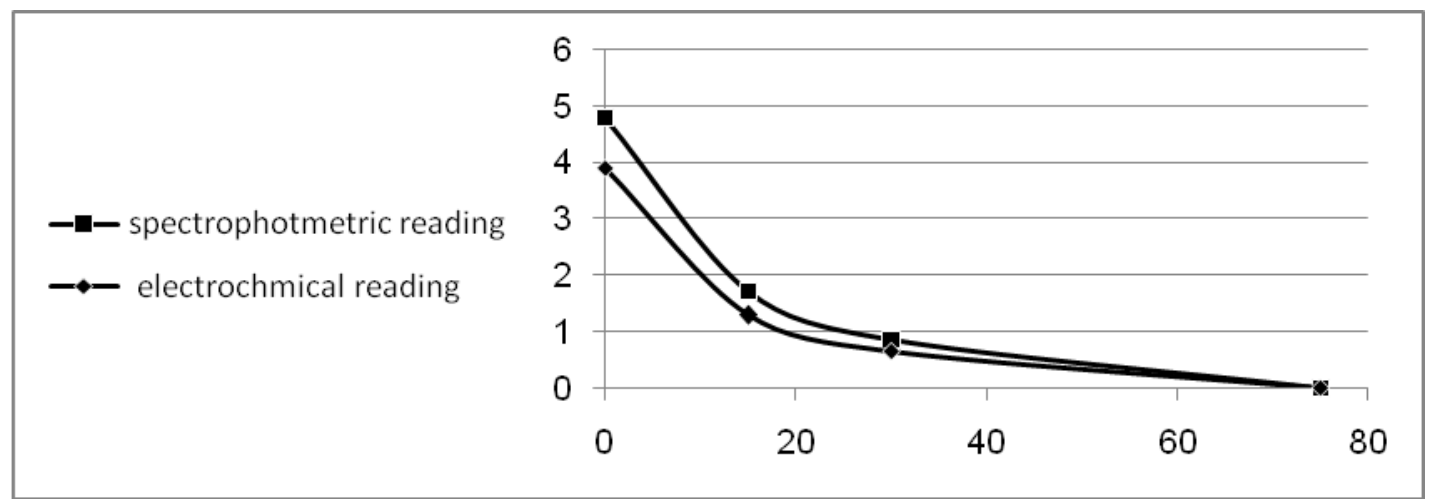

Figure 3: Comparison between biochemical and electrochemical detection methods

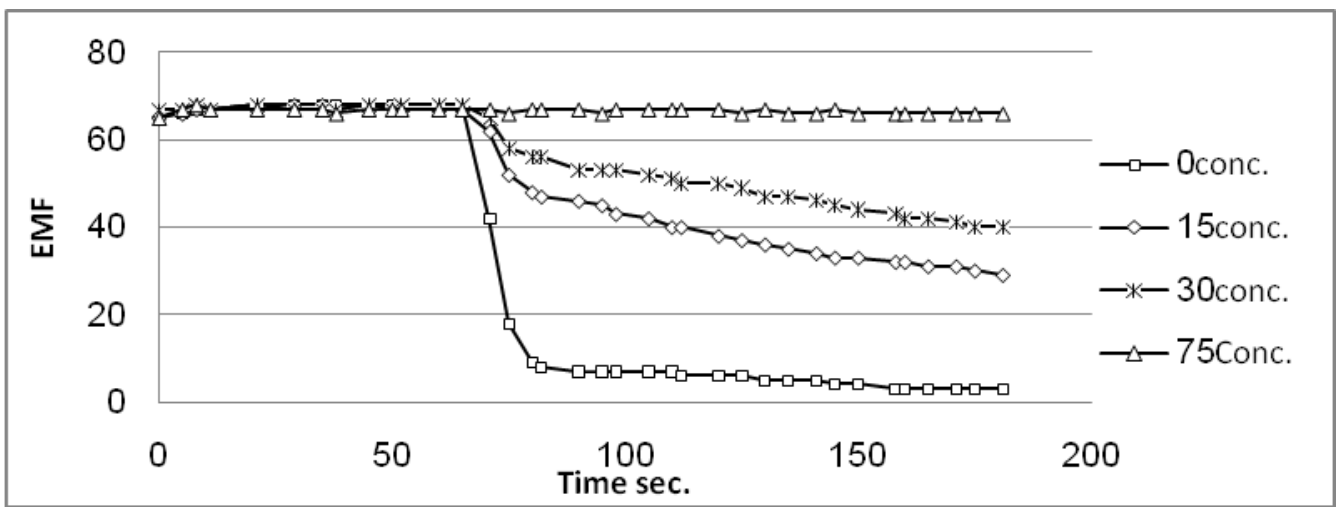

Figure 4: Potentiometric response of (TDMAC)-based Heparin-sensitive membrane electrodes towards

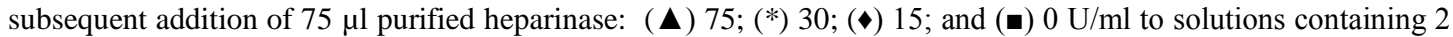
$\mu \mathrm{l} / \mathrm{ml}$ Heparin. Enzyme reaction was carried out at $25{ }^{\circ} \mathrm{C}$ for 20 minutes. 


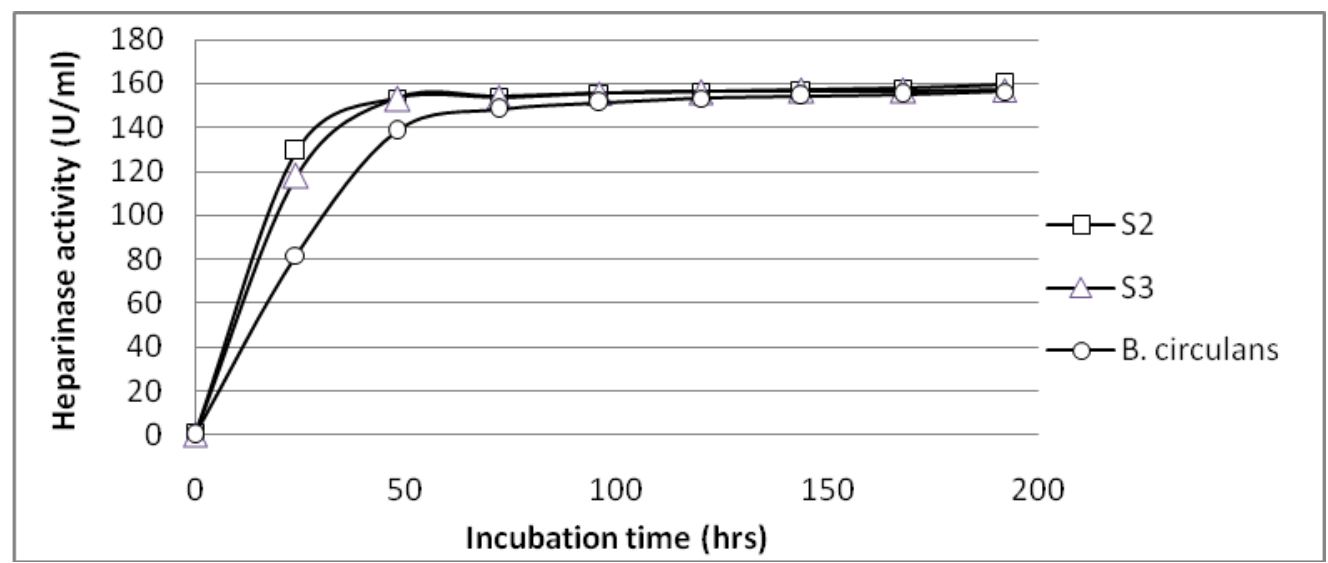

Figure 5: Heparinase production by isolates in PYH medium: $(\boldsymbol{\Delta}) \mathrm{S} 3 ;(\bullet)$ B. circulans; and (๘) S2

The results obtained in figure (5) showed that heparinase production by the $\mathbf{S 2}$ cultures was $159.6 \mathrm{U} / \mathrm{ml}$ after 192 hours of incubation. Enzyme production from $\mathbf{S 3}$ was $156.6 \mathrm{U} / \mathrm{ml}$ after 192 hours of incubation. B. circulans produced $153.8 \mathrm{U} / \mathrm{ml}$ after 192 hours of incubation. With further incubation heparinase production decreased for three cultures.

\subsubsection{Heparinase production by utilization chicken slaughter waste}

Isolate S2 was cultured in PYH medium supplemented with different concentration of dried blood waste $(1 \%, 5 \%, 10 \%, 15 \%$ and $20 \%)$ to test their production heparinase enzyme.

The results obtained in table (2) showed that heparinase production by $\mathbf{S 2}$ isolate grown on PYH medium supplemented with $15 \%$ chicken slaughter waste was gave the highest level of enzyme production $(162.1 \mathrm{U} / \mathrm{ml})$ after 192 hours of incubation.

Whereas, the growth curve of the isolate increased at $10 \%, 15 \%$ and $20 \%$ concentrations of chicken slaughter waste with further incubation, the heparinase production decreased after 192 hours. (Figure 6)

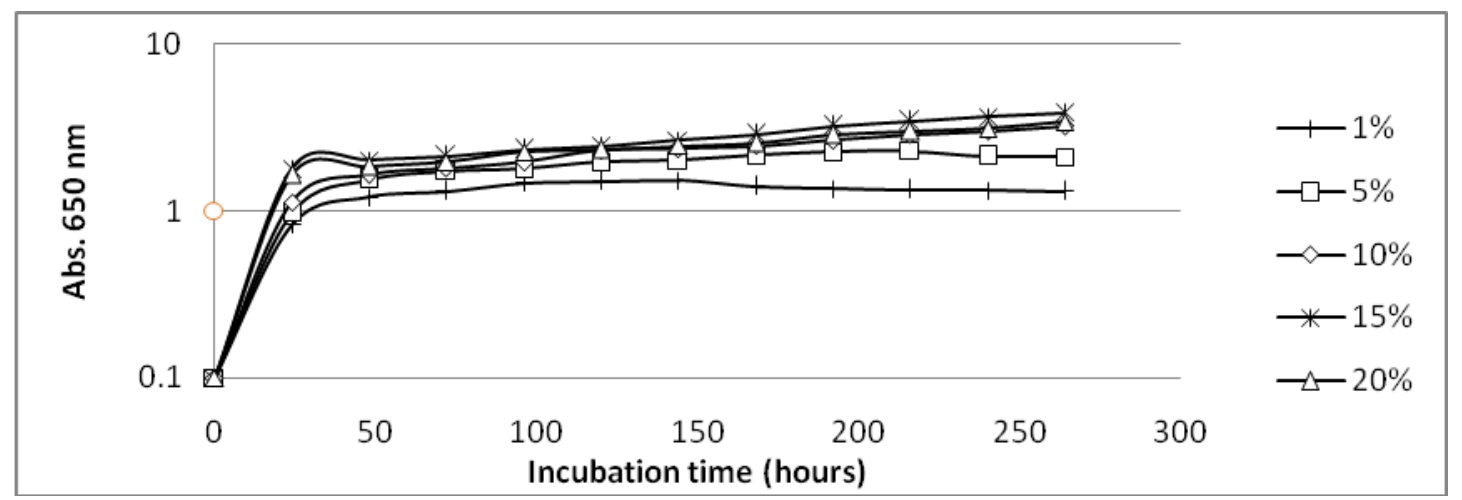


Figure 6: Growth curve of S2 in PYH medium supplemented with dried blood waste: ( $\boldsymbol{\Delta}$ ) 20

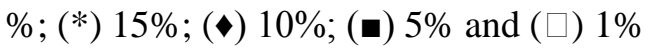

Table 2: Heparinase production of S2 grown on PYH medium supplemented with blood waste

\begin{tabular}{|c|ccccc|}
\hline \multirow{2}{*}{$\begin{array}{c}\text { incubation } \\
\text { time (hrs) }\end{array}$} & \multicolumn{5}{|c|}{ Dried blood waste percentage } \\
\cline { 2 - 6 } & $\mathbf{1 \%}$ & $\mathbf{5 \%}$ & $\mathbf{1 0 \%}$ & $\mathbf{1 5 \%}$ & $\mathbf{2 0 \%}$ \\
\hline $\mathbf{0}$ & 0 & 0 & 0 & 0 & 0 \\
$\mathbf{2 4}$ & 139.8 & 144.7 & 147.6 & 151.7 & 149.8 \\
$\mathbf{4 8}$ & 142.5 & 151.7 & 152.1 & 154.7 & 152.1 \\
$\mathbf{7 2}$ & 148.4 & 152.8 & 153.8 & 157.6 & 154.7 \\
$\mathbf{9 6}$ & 154.3 & 155.8 & 156.1 & 158 & 156.7 \\
$\mathbf{1 2 0}$ & 155.4 & 157.8 & 157.4 & 158.6 & 157.7 \\
$\mathbf{1 4 4}$ & 158 & 161.7 & 158.7 & 159.9 & 158.7 \\
$\mathbf{1 6 8}$ & 157.3 & 159.7 & 159.9 & 161.4 & 157.5 \\
$\mathbf{1 9 2}$ & 157.3 & 159.9 & 161 & 162.1 & 158 \\
\hline
\end{tabular}

\section{Optimization of heparinase production}

\subsubsection{Determination of optimum $\mathrm{pH}$}

The selected isolate (S2) was cultured in PYH medium at different value of $\mathrm{pH}(5.4,6.4,7.4$, 8.5, 9.5 and 10.5). Although, the growth curve of isolate increased at $\mathrm{pH} 9.5$ and $\mathrm{pH} 10.5$ with further incubation (Figure 7), the heparinase production decreased after 192 hours.

The results obtained in table (3) showed that heparinase production by the S2 isolate grown on PYH medium at $\mathrm{pH} 9.5$ give the highest level of enzyme production $(160.1 \mathrm{U} / \mathrm{ml})$ after 192 hours of incubation.

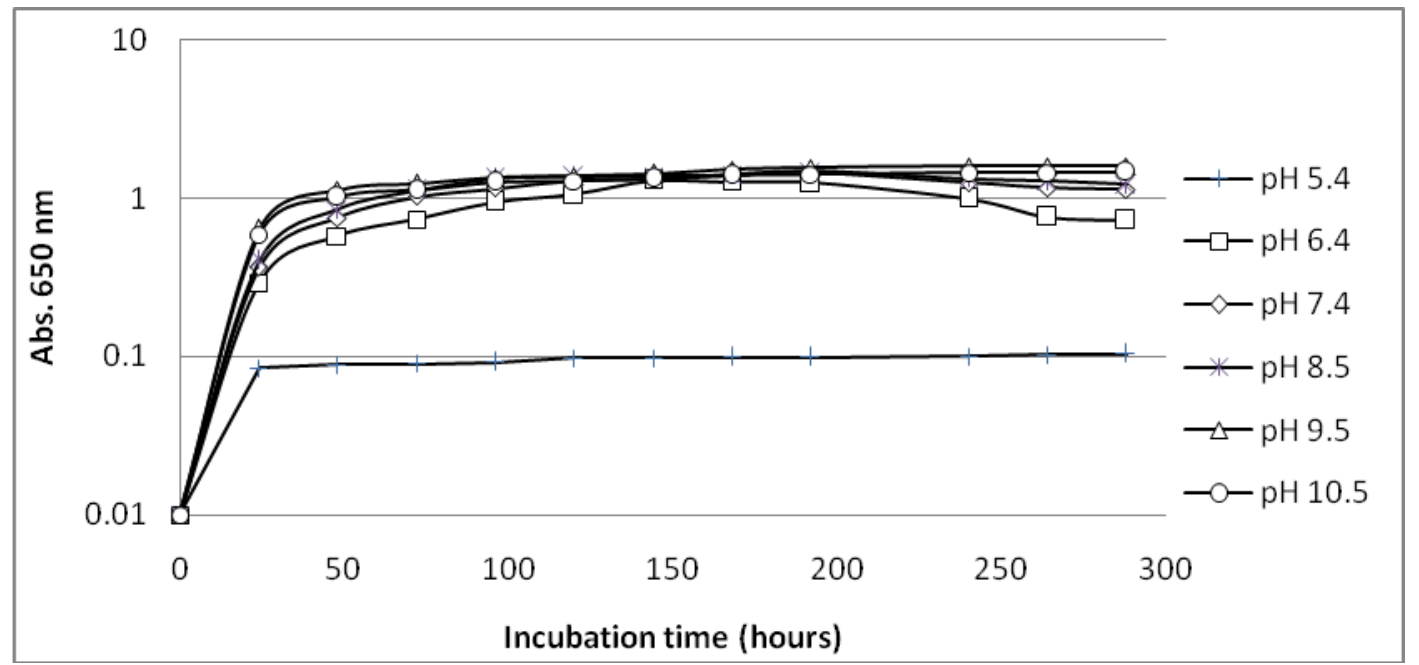

Figure 7: Growth curve of S2 in PYH medium at different value of $\mathrm{pH}:(\bullet) \mathrm{pH} 10.5 ;(\boldsymbol{\Delta}) \mathrm{pH} 9.5 ;(*) \mathrm{pH} 8.5 ;(\diamond) \mathrm{pH} 7.4 ;(\boldsymbol{\bullet}) \mathrm{pH}$ 6.4 and $(\square) \mathrm{pH} 5.4$ 
Table 3: Heparinase production of S2 in PYH medium at different value of pH

\begin{tabular}{|c|c|c|c|c|c|c|}
\hline $\begin{array}{c}\text { Incubation } \\
\text { time }\end{array}$ & $\begin{array}{c}\text { pH5. } \\
4\end{array}$ & $\begin{array}{l}\mathrm{pH} \\
6.4\end{array}$ & $\begin{array}{l}\text { pH } \\
7.4\end{array}$ & $\begin{array}{l}\text { pH } \\
8.5\end{array}$ & $\begin{array}{l}\text { pH } \\
9.5\end{array}$ & $\begin{array}{c}\text { pH1 } \\
0.5\end{array}$ \\
\hline $\mathbf{0}$ & 0 & 0 & 0 & 0 & 0 & 0 \\
\hline 24 & 0 & 5.1 & $\begin{array}{c}129 \\
.4\end{array}$ & $\begin{array}{c}115 \\
.6\end{array}$ & $\begin{array}{c}114 \\
.2\end{array}$ & $\begin{array}{c}144 . \\
2\end{array}$ \\
\hline 48 & 2.5 & $\begin{array}{c}113 \\
.6\end{array}$ & $\begin{array}{c}153 \\
.3\end{array}$ & $\begin{array}{c}152 \\
.8\end{array}$ & 152 & $\begin{array}{c}151 \\
8\end{array}$ \\
\hline 72 & 5.1 & $\begin{array}{c}127 \\
.5\end{array}$ & $\begin{array}{c}153 \\
.8\end{array}$ & $\begin{array}{c}153 \\
.4\end{array}$ & 153 & $\begin{array}{c}151 . \\
9\end{array}$ \\
\hline 96 & 5.1 & $\begin{array}{c}141 \\
.2\end{array}$ & $\begin{array}{c}155 \\
.5\end{array}$ & $\begin{array}{c}153 \\
.8\end{array}$ & $\begin{array}{c}152 \\
.8\end{array}$ & $\begin{array}{c}151 . \\
7\end{array}$ \\
\hline 120 & 5.1 & $\begin{array}{c}147 \\
.2\end{array}$ & $\begin{array}{c}156 \\
.2\end{array}$ & $\begin{array}{c}155 \\
.3\end{array}$ & $\begin{array}{c}154 \\
.8\end{array}$ & $\begin{array}{c}153 . \\
2\end{array}$ \\
\hline 144 & 5.1 & $\begin{array}{c}149 \\
.5\end{array}$ & $\begin{array}{c}156 \\
.9\end{array}$ & $\begin{array}{c}157 \\
.1\end{array}$ & $\begin{array}{c}156 \\
.6\end{array}$ & $\begin{array}{c}154 \\
8\end{array}$ \\
\hline 168 & 5.1 & $\begin{array}{c}150 \\
.1\end{array}$ & $\begin{array}{c}157 \\
.9\end{array}$ & $\begin{array}{c}158 \\
.1\end{array}$ & $\begin{array}{c}158 \\
.4\end{array}$ & $\begin{array}{c}156 . \\
4\end{array}$ \\
\hline 192 & 5.1 & $\begin{array}{c}151 \\
.2\end{array}$ & $\begin{array}{c}159 \\
.6\end{array}$ & $\begin{array}{c}159 \\
.7\end{array}$ & $\begin{array}{c}160 \\
.1\end{array}$ & $\begin{array}{c}158 . \\
3\end{array}$ \\
\hline
\end{tabular}

The selected isolates S2 were culture in PYH medium at different value of temperature $\left(25^{\circ} \mathrm{C}, 37^{\circ} \mathrm{C}\right.$, $45^{\circ} \mathrm{C}$ and $\left.55^{\circ} \mathrm{C}\right)$.

The results obtained in ( Figure 8) showed that heparinase production by the $\mathbf{S 2}$ isolate grown on PYH medium at $37^{\circ} \mathrm{c}$ give high rate of enzyme production $(159.6 \mathrm{U} / \mathrm{ml})$ after 192 hours of incubation and heparinase production decreased with further incubation time.

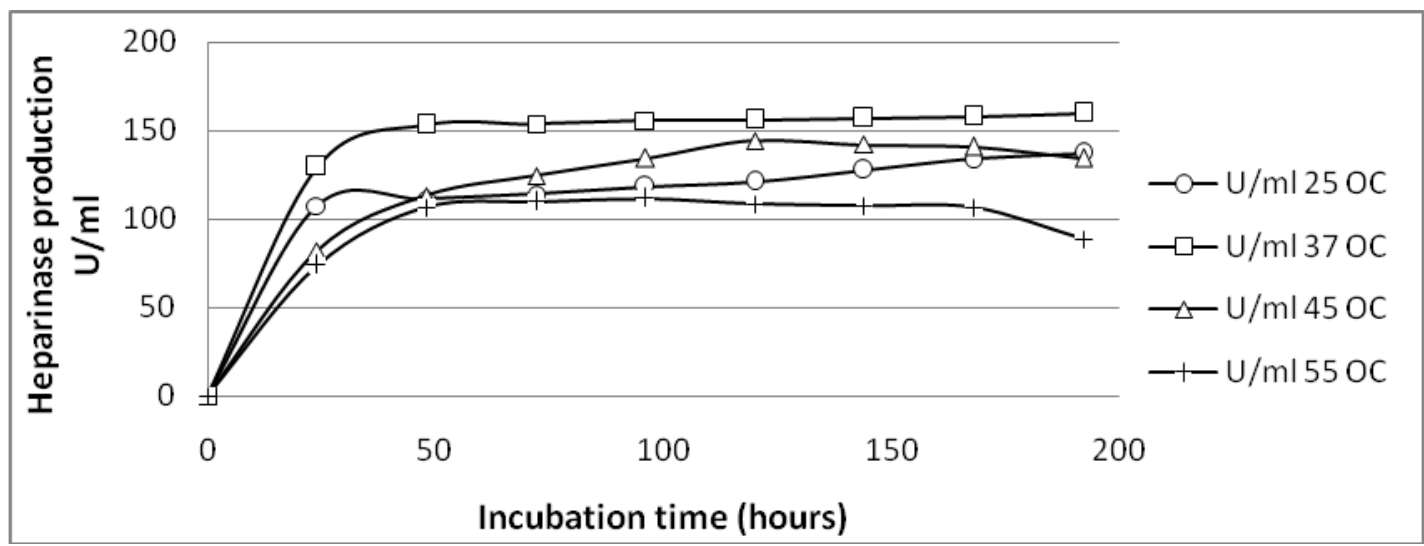

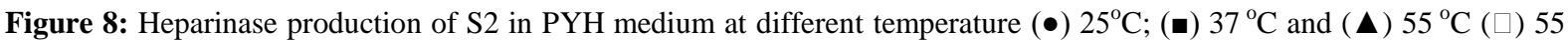
${ }^{\circ} \mathrm{C}$

Characterization of the selected isolate.

From twenty four isolates, one isolate (S2) was the most hyper producing microbe for heparinase enzyme production. It was subjected to further studies in order to be characterized and identified.

\section{Genotypic characterization of selected Isolate.}

The phylogenic tree for selected isolate S2 after the PCR product was compared with known sequences in the Gene Bank nucleotide database and identified as the nearest Phylogenetic neighbor with the highest similarity percent. The isolated strain was identified as Bacillus cereus ATCC 14579 (Figure 9) 


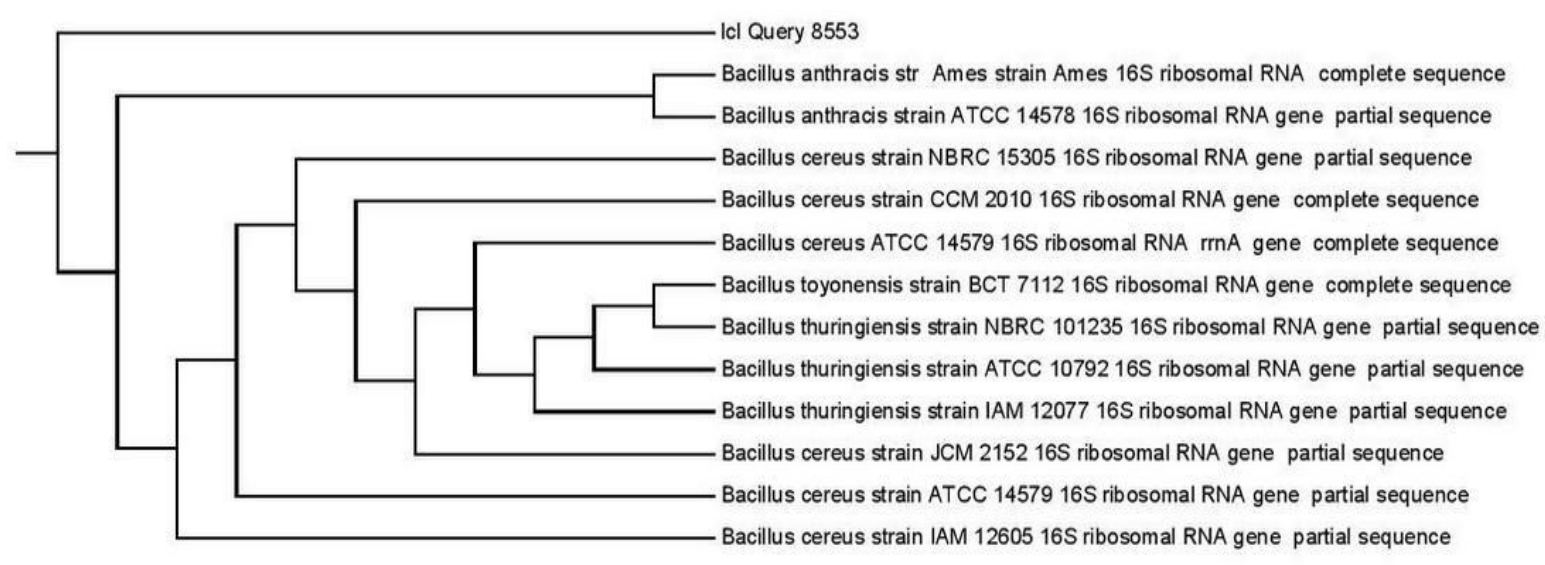

Figure 9: phylogenic tree for strain S2. According to Bergey's manual of Determinative Bacteriology, Ninth edition by Holt (2000) and 16s RNA gene technique the isolated strain was identified as Bacillus cereus ATCC 14579

\section{Sensitivity and Resistance to antibiotics}

The results obtained in table (4) showed that the Bacillus cereus was sensitive to (Nitrofurantoin, Amikacin, Gentamycin, Doxycycline, Norfloxacin, Ciprofloxacin Clindamycin and Chloramphenicol), resistance to (Ox tetracycline, Cefoxitin, Cefotaxim, Ampicillin, and Azithromycin) and intermediate to (Unictam, Cephradine, and Amox. Cluve)

Table 4: sensitivity and resistance to antibiotics

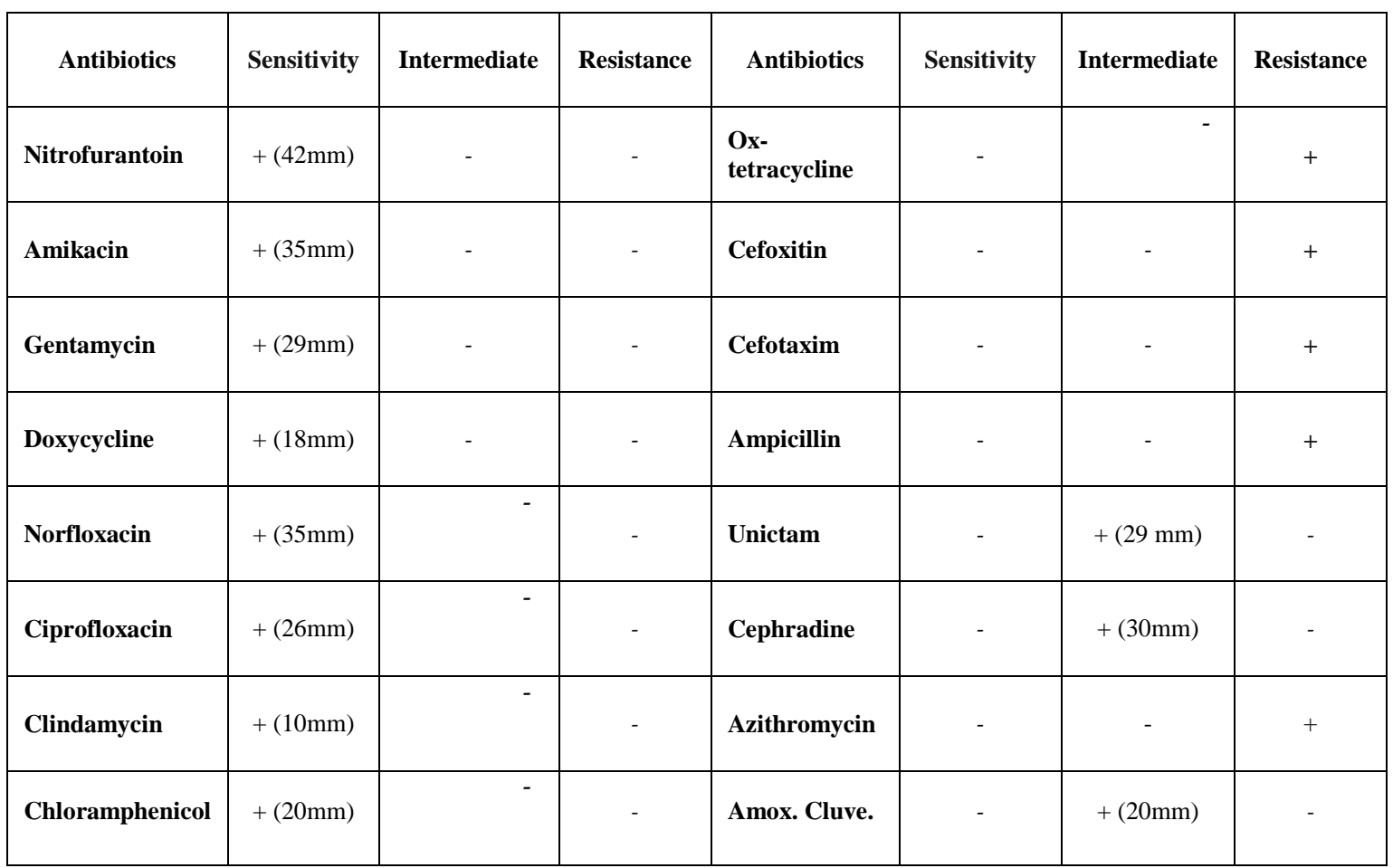

Purification of Heparinase Enzyme

Purification of heparinase enzyme was carried out firstly, by salting out the total protein containing heparinase enzyme which produced by Bacillus cereus strain in an ice-bath and stirred slowly then it was allowed to stand for 1 hour at $4^{\circ} \mathrm{C}$.

Optimization of ammonium sulfate precipitation

The results obtained in table (5) showed that precipitation of total proteins contained heparinase enzyme that produced by Bacillus cereus using different concentration of ammonium sulfate were precipitated with $60 \%$ ammonium sulfate and give high total protein content ( $161.09 \mathrm{mg}$ protein $/ \mathrm{ml}$ ) in pellet and ( $20.30 \mathrm{mg}$ protein $/ \mathrm{ml}$ ) in supernatant. So $60 \%$ was chosen as the optimum concentration of ammonium sulfate that precipitates heparinase enzyme.

Then, total protein precipitated by ammonium sulfate was dissolved in a minimal volume of $0.1 \mathrm{M}$ Tris- $\mathrm{HCl}$ buffer, $\mathrm{pH} 7.5$ and determined according to methods of Lowry. A standard curve was established each time using bovine serum albumin (BSA, Sigma).(figure 9) 


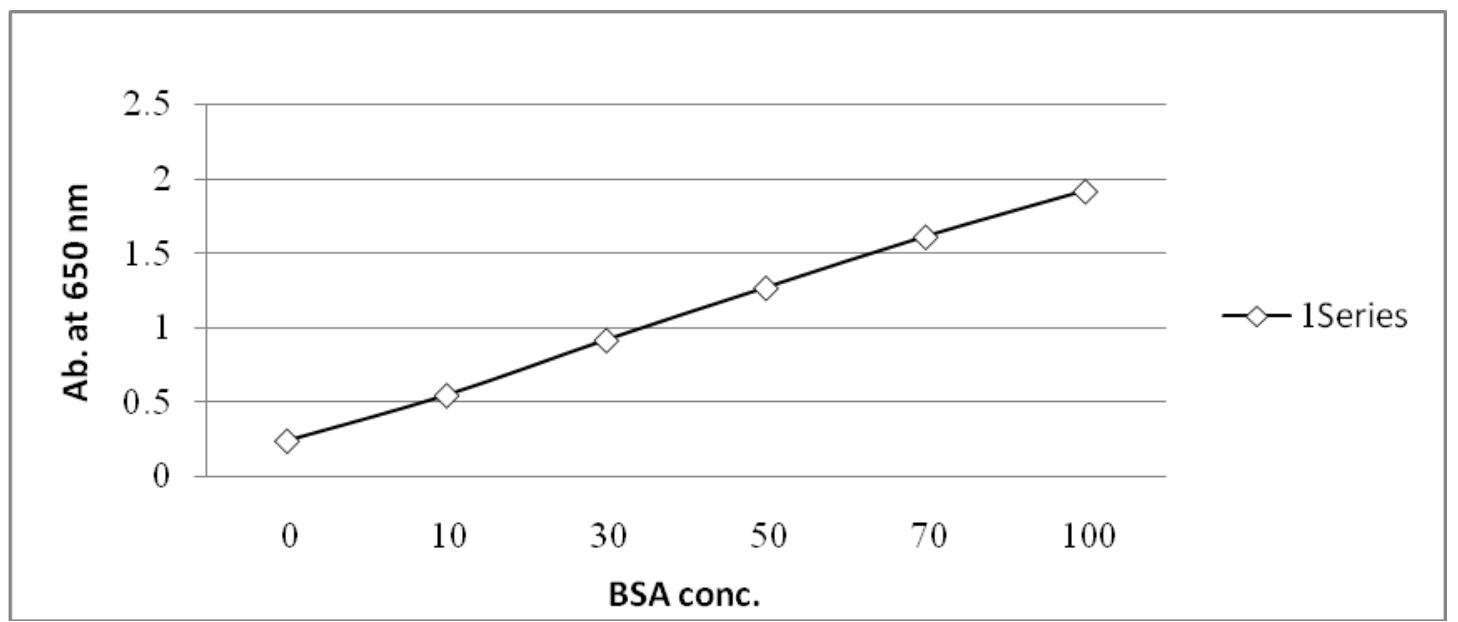

Figure 9: A standard curve of Bovine serum albumin

Subsequently, the total protein was dialyzed overnight against the same buffer at $4{ }^{\circ} \mathrm{c}$. One ml sample was taken from each crude enzyme solution to determine the protein content and the heparinase enzyme activity.

Table 5: Optimization of salting out of total proteins containing heparinase enzyme by different concentration of ammonium sulfate

\begin{tabular}{|c|c|c|c|c|c|c|}
\hline \multirow[t]{2}{*}{ Am.Sulfate \% } & \multicolumn{3}{|c|}{ Supernatant } & \multicolumn{3}{|c|}{ Pellet } \\
\hline & U/l & $\begin{array}{c}\text { mg } \\
\text { Protein/ml }\end{array}$ & $\begin{array}{l}\mathbf{S} \\
\mathbf{A}\end{array}$ & $\begin{array}{l}\text { U/ } \\
\text { ml }\end{array}$ & $\begin{array}{c}\text { mg } \\
\text { Protein/ } \\
\text { ml }\end{array}$ & SA \\
\hline 40 & $\begin{array}{c}11 \\
5.6\end{array}$ & 106.24 & $\begin{array}{l}1 . \\
09\end{array}$ & $\begin{array}{l}93 \\
6.7\end{array}$ & 75.30 & $\begin{array}{c}8.6 \\
6\end{array}$ \\
\hline 50 & $\begin{array}{c}14 \\
4.5\end{array}$ & 51.64 & $\begin{array}{l}2 . \\
80\end{array}$ & $\begin{array}{l}11 \\
70\end{array}$ & 132.20 & $\begin{array}{l}19 . \\
38\end{array}$ \\
\hline 60 & $\begin{array}{l}17 \\
3.4 \\
\end{array}$ & 20.30 & $\begin{array}{l}8 . \\
54\end{array}$ & $\begin{array}{l}64 \\
30\end{array}$ & 161.09 & $\begin{array}{l}39 . \\
92\end{array}$ \\
\hline 70 & $\begin{array}{r}15 \\
6.2\end{array}$ & 63.82 & $\begin{array}{l}2 . \\
45\end{array}$ & $\begin{array}{l}13 \\
02\end{array}$ & 116.20 & $\begin{array}{l}19 . \\
97\end{array}$ \\
\hline
\end{tabular}

\section{Discussion}

Protamine sulfate is a polycationic polypeptide with high arginine content. The Protamine sulfate and heparin reaction occurs due to their opposite surface charges; protamine as a polycation readily reacts with the polyanion heparin to form protamine-heparin complexes or aggregates ${ }^{(35)}$.

Incubation with $2 \%$ protamine sulfate solution resulted in a clearance zone around the bacterial growth, indicating utilization of heparin as substrate.

The results obtained in table (1) showed that three isolates produced high clear zone ranged from (2.7 - 35mm) for isolates S2, S3 and Bacillus circulans. The results of primary screening and heparinase plate assay are subjective and provide with little information of the level of heparinase activity produced by the microorganisms. Final selection of microorganisms was based on quantitative measurements of the heparinase activity under submerged culture conditions.

4.2. Comparison between different methods of enzyme assay

Extracellular heparinase was measured by different biochemical and electrochemical methods to validate and evaluate the most convenient and sensitive method for enzyme determination. To begin with, plate assay method was chosen to screen for the most hyper-producing isolate. After selection of six isolates, enzyme determination was carried out with spectrophotometric method using crystal violet as the cationic dye that coupled with the substrate heparin. Simultaneously, heparinase was detected using TDMAC polyanion heparinsensitive electrode. The polyanion electrode was calibrated with different concentrations of heparin starting from zero to $2 \mathrm{mg} / \mathrm{ml}$.

Results obtained from both biochemical and electrochemical detection methods were so close (Figure 3) giving a good chance to choose between the two methods according to the proper reaction conditions.

Figure (4) shows the enzymatic activity of extracellular heparinase produced by Bacillus cereus after growing the microbe on PYH medium for more than 8 days. Detection was carried out with different concentrations of partially purified enzyme starting from 0 units per $\mathrm{ml}$. The electrochemical method offered a fast, cheap, 
sensitive and very reliable method in enzyme detection specially when measuring it in turbid solutions similar to biological media.

\section{Heparinase production in submerged culture Heparinase production in PYH media}

Submerged cultures of the two selected microorganisms (from Figure 1) were prepared in Enrichment culturing liquid medium, where heparin acted as an inducer and sole carbon source, was used to select microorganisms on the basis of heparinase production.

Heparinase production of the selected isolates was achieved by growing the microorganisms on $\mathrm{PYH}$ medium. Isolates were compared according to their heparinase production. (Figure 2)

Consequently, two selected isolates (S2\&S3) and Bacillus circulans were cultured in PYH medium for heparinase production. S2 was isolated from (SWS) and collected from Greace Slaughter and S3 was isolated from (FYM) collected from Abou Awally village.

\section{Conclusion}

Aim of this study was oriented to utilize chicken slaughter waste to produce useful compounds such as heparin degrading enzyme by bioremediation techniques. The results showed that Bacillus cereus isolated from screening of waste samples collected from El-Menoufia Governorates in Egypt gave the highest production value of heparin degrading enzyme. Then, the microbe was used to produce heparinase enzyme upon biodegradation of chicken slaughter by-products. Subsequently, experiments were carried out for optimization of $\mathrm{pH}$ and temperature to enhance the growth curve and enzyme production of the isolate. Results showed that optimum $\mathrm{pH}$ was 9.5 and optimum temperature was $37^{\circ} \mathrm{C}$.

Extracellular heparinase was determined by spectrophotometric and electrochemical methods to validate and evaluate the most convenient and sensitive method for enzyme detection through growth of selected isolate. The electrochemical method offered a fast, cheap, sensitive and very reliable method in enzyme detection specially when measuring it in turbid solutions similar to biological media. Results obtained from both biochemical and electrochemical detection methods were so close giving a good chance to choose between the two methods according to the proper reaction conditions.

Purification of heparinase enzyme was carried out firstly, by salting out using $60 \%$ ammonium sulfate. The enzyme was further purified by gel filtration on a (Sephadex G-50) column. Results obtained showed that the purified heparinase enzyme produced by Bacillus cereus gave specific activity of $152.12 \mathrm{U} / \mathrm{mg}$ proteins giving an optimistic result for initiating a commercial production of extracellular heparinase from that microbe upon useful biodegradation of agricultural as well as domestic wastes.

\section{Conflict of interest statement:}

The authors declares no conflicts of interest.

\section{References}

1. Karigar and Shwetha S. Rao (2011): Role of Microbial Enzymes in the Bioremediation of Pollutants. Enzyme Research. Volume 2011, Article ID 805187, 11 pages

2. Shriver, Z., Sundaram, M., Venkataraman, G., Fareed, J., Linhardt, R., Biemann, K. and Sasisekharan, R. (2000), Cleavage of the antithrombin III binding site in heparin by heparinases and its implication in the generation of low molecular weight heparin. Proc Natl Acad Sci USA 97: 1036510370 .

3. Hillman R. S. (2010): Integrated patient management and control system for medication delivery, US patent.

4. Mousa S. A. (2002). The low molecular weight heparin, tinzaparin, in thrombosis and beyond. Cardiovasc. Drug Rev., 20: 199-216.

5. Melnikova I. (2009), The anticoagulants market. Nat. Rev. Drug Discov., 8: 353-354.

6. Sasisekharan R., Moses M. A., Nugent M. A., Cooney C. L. and Langer R. (1994), Heparinase inhibits neovascularization. Proc. Natl. Acad. Sci. USA, 91: 1524-1528.

7. Dongfang, L., Pojasek, K., Shriver, Z., Holley, K., Elshabrawi, Y., Venkataraman, G. and Sasisekharan, R.. (2002) Heparinase III and uses thereof. European Patent 1:266,013.

8. Amirkhosravi A., Mousa S. A., Amaya M. and Francis J. L. (2003), Antimetastatic effect of tinzaparin, a low-molecularweight heparin. J.Thromb. Haemost., 1:1972-1976.

9. Collen A, Smorenburg SM, Peters E, Lupu F and Koolwijk P (2000).Unfractionated and low molecular weight heparin affect fibrin structure and angiogenesis in vitro. Cancer Res 60: $6196-$ 6200 .

10. Jacques, L.B. (1979): Heparin: an old drug with a new paradigm. Science 206: 528- 533.

11. Wahlin, B., Hans-Peter Ekre, Johan Carlson, Asli A. Kulane, Peter Perlmann and Mats Wahlgren (1995) Fractionated heparin for the therapeutic treatment of malaria. US Patent 5,472,953.

12. Lohse, D. and Linhardt, R. (1992) Purification and characterization of heparin lyases from Flavobacterium heparinum. J Biol Chem 267: 24347-24355.

13. Salyers A. A., Vercellotti J. R., West S. E. and Wilkins T. D. (1977), Fermentation of mucin and plant polysaccharides by strains of Bacteroides from the human colon. Appl. Environ. Microbiol., 33: 319-322.

14. Nakamura T., Shibata Y. and Fujimura S. (1988), Purification and properties of Bacteroides heparinolyticus heparinase (heparin lyase, EC 4.2.2.7). J. Clin. Microbiol., 26: 1070-1071.

15. Yapeng, C., Ningguo, G., Xiulan, C., Jing, Y., Shijun, Q. and Shuzheng, Z. (2003) Rapid Purification, characterization and substrate specificity of heparinase from a novel species of Sphingobacterium. J Biochem 134: 365-371.

16. Yoshida E., Sakai K., Tokuyama S., Miyazono H., Maruyama H., Morikawa K., Yoshida K. and Tahara Y. (2002), Purification and characterization of heparinase that degrades both heparin and heparan sulfate from Bacillus circulans. Biosci. Biotechnol. Biochem., 66: 1181-1184.

17. Kim, W. S., Kim, B. T., Kim, D. H., \& Kim, Y. S. (2004). Journal of Biochemistry and Molecular Biology, 37: 684-690.

18. Banga,J. and Tripathi, C.K.M. (2009) Rapid Purification and Characterization of a novel heparin degrading enzyme from Acinetobacter calcoaceticus. New Biotechnol., 1: 99-104.

19. Banga, J. and Tripathi, C.K.M. (2010) Purification and characterization of a novel heparin degrading enzyme from 
Aspergillus flavus (MTCC-8654). Appl. Biochem. Biotechnol. , 1:1004-1016

20. Bernhard, K., H. Schrempf, and W. Goebel (1978). Bacteriocin and antibiotic resistance plasmids in Bacillus cereus and Bacillus subtilis. J. bacterial. 133:897-903.

21. Payza, A. N. and Korn, E. D., (1956): The degradation of heparin by bacterial enzymes. I. Adaptation and lyophilized cells. J. Biol. Chem., 223: 853858.

22. Zimmermann J. J., Langer R. and Cooney C. L. (1990), Specific plate assay for bacterial heparinase. Appl. Environ. Microbiol., 56: 3593-3594.

23. Sun, Han, Q- J. Li and K. Jiao (2007): Spectrophotometric and Voltammetric Studies on the Interaction of Heparin with Crystal Violet and its Analytical Application" S. Afr. J. Chem., 60: $42-46$.

24. Durust, N. and Meyerhoff, M.E. (2001). Determination of pentosan polysulfate and its binding to polycationic species using polyion-sensitive membrane electrodes. Anal. Chim. Acta, 432: $253-260$

25. Williams, S. T., Locci, R., Beswick, A., Kurtboke, D. I., Kuznetsov, V. D., Lemonnior, F. J. and Long, P. F. (1993):Detection and identification of novel actinomycetes. Res Microbiol, 144: 653- 656.

26. Macfaddin, J. F. 2000. Biochemical Tests for Identification of Medical Bacteria, Third Ed. Lippincott Williams \& Wilkins, 227 East Washington Square, Philadelphia, PA 19106.

27. Gordon, J. and Mcleod, J. W. (1923). The practical application of the direct oxidase reaction in bacteriology. J. Path. Bact. 31: 185-190.
28. Gaby, Hadley (1957): Practical laboratory test for the identification of Pseudomonas aeruginosa, J. Bacterial., 74: 356-358

29. Kovacs, N. (1956). Identification of Pseudomonas pyocyanea by the oxidase reaction. Nature, Lond., 178: 703.

30. Ibrahim A., Gerner-Smidt P. and Liesack W. (1997): Phylogenetic relationship of the twenty-one DNA groups of the genus Acinetobacter as revealed by $16 \mathrm{~S}$ ribosomal DNA sequence analysis. Int. J. Syst. Evol. Microbiol., 47: 837-841. 31. Goodfellow, M. and Orchard, V. A. (1974): Antibiotic sensitivity of some nocardioform bacteria and its value as a criterion for taxonomy. Journal General of Microbiology, 83: 375-387.

32. Mantsala, p., and H. Zalkin(1980). Extracellular and membrane-bound proteases from Bcillus subtilis. J .Bacteriol. 141:493-501

33. Lowry, O. H., Rosebrough, N. J., and Randall, A. L., (1951). Protein measurement with the folin phenol reagent. J. Biol. Chem., 193: 265-275

34. Maniatis, T.; E.F. Fritsch, and J. Sambrook (1982). Molecular cloning: A Laboratory Manual. Cold Spring Harbor Laboratory.Cold Spring Harbor NY, USA.

35. Rossmann P., Matousovic K. and Horacek V. (1982), Protamine-heparin aggregates. Their fine structure, histochemistry, and renal deposition. Virchows Arch. B Cell. Pathol. Incl. Mol. Pathol., 40: 81-98. 